\title{
Short Communication: \\ In vitro antimicrobial and antimalarial screening of a crude extract of Streptomyces sp. AB8 isolated from Lapindo Mud Volcano Area, Sidoarjo, Indonesia
}

\author{
ACHMAD ARIFIYANTO ${ }^{1, \bullet}$, ENDAH SETYANINGRUM ${ }^{1}$, NISMAH NUKMAL ${ }^{1}$, TITIK NUR AENY ${ }^{2}$ \\ ${ }^{1}$ Department of Biology, Faculty of Mathematics and Natural Sciences, Universitas Lampung, Jl. Prof. Soemantri Brojonegoro No 1, Gedong Meneng, \\ Rajabasa, Bandarlampung 35144, Lampung, Indonesia, Tel.: +62-721 704625 Fax.+62-721 704625, `email: achmad.arifiyanto@ fmipa.unila.ac.id \\ ${ }^{2}$ Department of Plant Protection, Faculty of Agriculture, Universitas Lampung, Jl. Prof. Soemantri Brojonegoro No 1, Gedong Meneng, Rajabasa, \\ Bandarlampung 35144, Lampung, Indonesia
}

Manuscript received: 5 April 2021. Revision accepted: 22 June 2021.

\begin{abstract}
Arifiyanto A, Setyaningrum E, Nukmal N, Aeny TN. 2021. Short Communication: In vitro antimicrobial and antimalarial screening of a crude extract of Streptomyces sp. AB8 isolated from Lapindo Mud Volcano Area, Sidoarjo, Indonesia. Biodiversitas 22: 2817-2823. Streptomyces is a potential bacterial genus that has been investigated extensively as a source of natural microbial compounds. Its potential metabolites have been widely developed for pharmaceutical, pathogen control, and other applications in agriculture. This study aimed to determine the ability of the Streptomyces sp AB8 crude extract in inhibiting Plasmodium and pathogenic microbes. Streptomyces was cultured on Gause synthetic media for 10 days. The fermented broth culture media has dissolved in a 1:1 mixture of ethyl acetate and methanol. Biochemical characterization of this isolate has carried out using the standard methods. In-vitro antimalarial activity assay was performed using a chloroquine-sensitive Plasmodium falciparum strain 3D7. Fresh type O-positive human erythrocytes were suspended at 4 percent hematocrit in a complete medium to maintain culture. The inhibitory concentration $\left(\mathrm{IC}_{50}\right)$ was determined using probit analysis. The results showed the extract of Streptomyces sp. AB8 contains phenolic and alkaloids. Streptomyces sp. AB8 extract can inhibit Dickeya zeae N-Unila 5, Dickeya zeae N-Unila 10, Aspergillus sp IK3, and Escherichia coli growth. The results also showed that the ICso value of extract against $P$. falciparum 3D7 was $17.56 \mathrm{ug} / \mathrm{mL}$. Further research was needed to determine the types of purified bioactive compounds and their bioactivity.
\end{abstract}

Keywords: Alkaloids, antimalarial, antimicrobial, phenolic, Streptomyces

\section{INTRODUCTION}

Malaria is a disease caused by the Plasmodium parasite, is one of the deadliest diseases in tropical countries (Hay et al. 2004). It was transmitted by the bite of a female Anopheles sp. infected with Plasmodium. Malaria in humans was caused by five different Plasmodium species, i.e., Plasmodium falciparum, Plasmodium vivax, Plasmodium malariae, Plasmodium ovale, and Plasmodium knowlesi (Singh et al. 2013).

Unfortunately, the Plasmodium sp. parasite was resistant to antimalarial drugs such as chloroquine, amodiaquine, mefloquine, and artemisinin, according to many studies (Cui et al. 2015). Malaria research was actively being conducted to combat parasite resistance. The analysis of metabolites from different plants has been performed (Alkandahri et al. 2019; Fatmawaty et al. 2017; Okokon et al. 2017; Orabuezea et al. 2020; Zeleke et al. 2017), as well as metabolites from microorganisms to combat multi-drug resistant Plasmodium. Metabolites derived from microbes were considered to be more desirable due to their shorter life cycles.

Streptomyces, a Gram-positive bacteria, is a member of the actinobacteria phylum which is known to have antimicrobial, anticancer (El-Naggar and El-Ewasy 2017), anti-inflammatory (Gomathi and Gothandam 2019), and antioxidant (Li et al. 2018). Several Streptomyces, such as Streptomyces hygroscopicus subsp. hygroscopicus (Fitri et al. 2019; Nugraha et al. 2020), Streptomyces SUK10 (Zin et al. 2017), and Streptomyces spectabilis BCC 4785 (Isaka et al. 2002) have been studied for their antimalarial activity. Streptomyces sp. AB8 was obtained from the Lapindo mud volcano (Arifiyanto et al. 2020), has not been investigated for its antimalarial activity. This study aimed to conduct an initial screening of the antimicrobial and antimalarial activity of Streptomyces sp. AB8.

\section{MATERIALS AND METHODS}

\section{Culture and fermentation}

Streptomyces sp. strain AB8 was rejuvenated on yeast starch agar (YSA) medium, Yeast Starch Agar medium consisted of $2.0 \mathrm{~g}$ yeast extract $\left(\mathrm{Oxoid}^{\mathrm{TM}}\right), 10.0 \mathrm{~g}$ soluble starch (Sigma-Aldrich), $15.0 \mathrm{~g}$ of agar powder (SigmaAldrich), and $1000 \mathrm{~mL}$ distilled water adjusted to a $\mathrm{pH}$ 7.3. Bacteria were cultured at room temperature for 1-5 days. The bacterial stock was cultured on a slanting agar medium. According to Arifiyanto et al. (2021) and Ezeonu 
and Ejikeme (2016), Bacteria were characterized by several biochemical tests.

Gause's medium consists of soluble starch, $\mathrm{KNO}_{3}$, $\mathrm{NaCl}, \mathrm{MgSO}_{4} .7 \mathrm{H}_{2} \mathrm{O}, \mathrm{K}_{2} \mathrm{HPO}_{4}, \mathrm{FeSO}_{4} .7 \mathrm{H}_{2} \mathrm{O}$, and distilled water was used as the fermentation medium (Lin et al. 2012). One loop of bacterial inoculum was added to 100 $\mathrm{mL}$ of Gause's medium. The fermentation was carried out at a speed of $150 \mathrm{rpm}$ in a shaking incubator at room temperature. Bacterial growth was observed for 10 days and measured using a spectrophotometer at $600 \mathrm{~nm}$ wavelength. A free-cell supernatant was separated from cell biomass using centrifugation at a speed of $6000 \mathrm{rpm}$, for 10 minutes. The supernatant was filtered through filter paper and extracted using a 1:1 methanol-ethyl acetate. A rotary evaporator was used to evaporate the solvent at 40$50^{\circ} \mathrm{C}$ for 40 minutes to obtain concentrate extract and was subsequently lyophilized into powder (Setyaningrum et al. 2021).

\section{Antimicrobial activity}

Fourteen day-olds of Aspergillus IK3 in a test tube were added with sterile distilled water parasite, then one percent molasses and $0.5 \mathrm{~mL}$ Tween 80 were added to the test tube, and homogenized using a vortex mixer. Conidia's suspension separated, then fungal spore cell density was adjusted to $10^{8}$ cells $/ \mathrm{mL}$ using a hemocytometer. It was observed under a microscope with 400x magnification (Agustina et al. 2019; Rosa et al. 2020).

Some swabs of bacterial suspension ages 18-24 hours were taken and then put into a test tube containing $5 \mathrm{~mL}$ of sterile $0.9 \% \mathrm{NaCl}$ so that the turbidity was comparable to that of 0.5 McFarland suspension (Darmawan et al. 2017; Putri et al. 2021).

E. coli and Dickeya zeae were grown on Mueller Hinton Agar (MHA) at a $10^{8} \mathrm{CFU} / \mathrm{mL}$ density in a Petri dish. One loop of Streptomyces sp. AB8 aged 24-hour was inoculated on media and challenged in the center of MHA media that has been inoculated with bacteria. An antifungal test was conducted on Potato Dextrose Agar media against Aspergillus IK3. Clear zones formation was observed after 24 hours of incubation at room temperature (Sumardi et al. 2020).

\section{In vitro antimalarial assay}

The in vitro antimalarial activity test was carried out using chloroquine-sensitive Plasmodium falciparum strain 3D7. As much as $1 \mathrm{mg}$ of the extract was dissolved in 100 $\mu \mathrm{L}$ of DMSO (concentration $10.000 \mu \mathrm{g} / \mathrm{mL}$ ) as a stock solution. The stock solution was diluted serially. Synchronous parasites (ring stage) with about $1 \%$ parasitemia were used in this test. Fresh type O-positive human erythrocytes were suspended at 4 percent hematocrit in a complete medium to maintain culture (Baniecki et al. 2007). Using a high-throughput liquid handler, parasites were supplemented into a 96-well plate. Two microliters of the test solution with various concentrations were added to the well. The final concentrations of the extract were $100,10,1,0.1$, and 0.01 $\mu \mathrm{g} / \mathrm{mL}$. The gas mixture $\left(\mathrm{O}_{2} 5 \%, \mathrm{CO}_{2} 5 \%, \mathrm{~N}_{2} 90 \%\right)$ was applied to the test plate that has been inserted into the chamber. The chamber containing the test plate was incubated for 48 hours at $37^{\circ} \mathrm{C}$. The culture was then harvested and a thin blood layer was made with $20 \%$ Giemsa staining.

Data were analyzed by counting the number of infected erythrocytes per 1000 normal erythrocytes to determine the growth percentage of Plasmodium and inhibitory activity of the extract against Plasmodium. A blood smear was observed under a microscope. The growth percentage was calculated using the following formula;

$$
\% \text { growth }=\% \text { parasitemia }-\mathrm{D} 0
$$

Where: D0 is the initial hour of growth (\%)

The inhibition ability is expressed as a percentage using the formula below:

The percentage of inhibition $=100 \%-((\mathrm{Xu}-\mathrm{Xk}) \mathrm{x} 100 \%)$

Where:

$\mathrm{Xu}=\%$ growth on the test solution

$\mathrm{Xk}=\%$ growth on the negative control

The two formulas above were used to determine the concentration of extract to inhibit the growth of parasites by $50 \%$. The lethal concentration $50\left(\mathrm{LC}_{50}\right)$ was estimated using probit analysis based on data of the inhibition percentage.

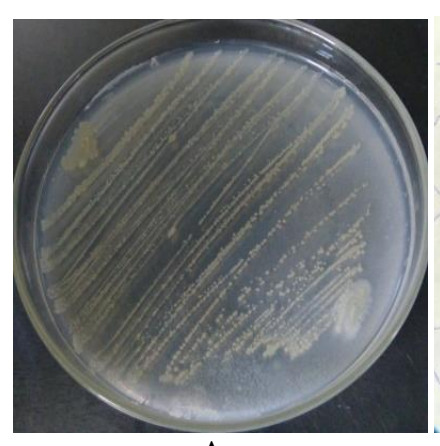

A

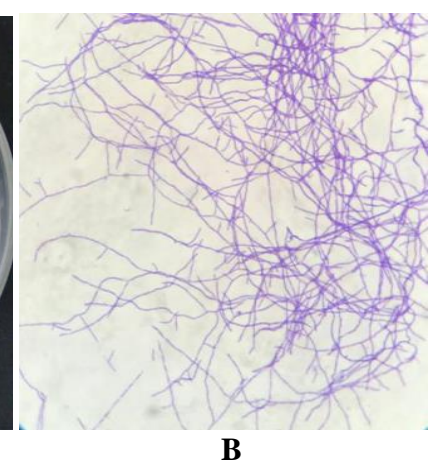

$\mathbf{B}$
Figure 1. A. Colonies of Streptomyces AB8 on Yeast Starch Agar; and B. The Gram-stained colony observed under microscope with 1000x magnification 


\section{RESULTS AND DISCUSSION}

\section{Antimicrobial activity of Streptomyces extract}

Streptomyces sp. AB8 bacteria were isolated from rhizosphere soil in the Lapindo mud volcano field, Sidoarjo. Previous research showed that Streptomyces sp. AB8 could inhibit the growth of pathogenic bacteria (Staphylococcus aureus ATCC 6538P and Escherichia coli ATCC 25922) (Arifiyanto et al. 2020). Dickeya zeae as a causative agent of stem and root rot in agricultural and plantation commodities (Aeny et al. 2020) was also inhibited by Streptomyces sp. AB8 (Table 1). The results suggested that crop damage caused by $D$. zeae could be controlled by the extract of Streptomyces sp. AB8 to overcome economic losses. These bacteria could also inhibit the growth of Aspergillus IK3, a cockroach pathogen, and Escherichia coli, which was isolated from wastewater around the campus of the University of Lampung.

Streptomyces is a Gram-positive bacteria that belong to the order Actinobacteriales with branched mycelium and chain-shaped. These bacteria could grow in a variety of environments, such as rhizosphere, marine debris, weathered leaf litter, plant endophytes, and insect symbionts (Mathew et al. 2020). The initial screening revealed that Streptomyces sp. AB8 could utilize glucose, fructose, cellulose, and lactose, galactose, sucrose, chitin, mannan, and amylum (Table 2) as its carbon source. As a decomposer group of microbes, Streptomyces has the ability to degrade complex molecules such as cellulose and mannan (Sasongko et al. 2015). Chitin is the main component of fungal cell walls. Streptomyces ability to decompose chitin potentially used to control mold. (Okay et al. 2013).

\section{Biochemical characterization of Streptomyces $\mathrm{sp.} \mathrm{AB8}$}

The development of new drug candidates has been driven by the resistance of pathogenic microbes to antibiotics and the risk to human health they pose. Microbial metabolites are increasingly being used to treat harmful bacteria. Streptomyces, a Gram-positive bacteria, have been shown to restrict the growth of various harmful bacteria. This bacterial community was thought to be in the middle of the bacteria-mold spectrum producing superior secondary metabolites such as triterpenoids, flavonoids, and alkaloids, and antibiotics. Gram-negative bacteria and pathogenic fungi were a challenge for humans health (AlAnsari et al. 2019). Some of them were responsible for infection in humans. Pathogenic bacteria such as Enterobacter aerogenes and Proteus mirabilis were confirmed to be inhibited by Streptomyces radiopugnans, Streptomyces atacamensis, Streptomyces fenghuangensis, Streptomyces verrucosisporus, and Streptomyces mangrove isolates (Al-Ansari et al. 2019). In humans, Aspergillus genera cause diseases such as localized infections, deadly illnesses, allergic responses, and inhaled conidia (Mousavi et al. 2016). Production of lyase, chitinase, protease, and cellulase enzymes by Streptomyces is suspected of supporting antifungal activity. These enzymes can damage the cell wall of the mold, which was rich in components that were easily degraded by these enzymes. Therefore, Streptomyces spp could be used as antifungals (de Lima Procópio et al. 2012).

There are several pathways of antimicrobial mechanisms of Streptomyces compounds. In general, antimicrobial mechanisms are the interactions of pathogenic microorganisms' biochemical, genetic, and cellular structures. (Chevrette et al. 2019). Metabolites of Streptomyces spp may cause the inhibition of DNA division. Disorders of RNA synthesis affect the ability of pathogens to produce proteins that play an important role in the cellular structure of membranes, functional enzymes, and the cell walls of pathogenic microbes. They were also inhibited pathogenic metabolism and structural breakdown (de Lima Procópio et al. 2012).

Alkaloids and phenols were detected in synthetic Gause broth after the fermentation process (Table 2). Alkaloids are present in a variety of plants and animals, including microbes. Alkaloids extracted from biological compounds had long been used to treat a range of symptoms (Zhou et al. 2013), such as cancer, painkillers, high blood pressure, nervous system damage, Parkinson's disease, and antimalarials were among them. Meanwhile, indole alkaloids isolated from Streptomyces sp. CT37 has been demonstrated to inhibit Candida albicans ATCC 10231 at low concentrations (Fang et al. 2020).

Table 1. The diameter of the growth inhibition by Streptomyces sp. AB8

\begin{tabular}{lcc}
\hline Microbes & $\begin{array}{c}\text { Colony diameter } \\
(\overline{\mathbf{x}} \mathbf{~ m m})\end{array}$ & $\begin{array}{c}\text { Clear zone } \\
(\overline{\mathbf{x}} \mathbf{~ m m})\end{array}$ \\
\hline Escherichia coli & 0.56 & 0.40 \\
Dickeya zeae N-Unila 5 & 1.60 & 0.70 \\
Dickeya zeae N-Unila 10 & 1.50 & 0.50 \\
Aspergillus sp IK3 & 0.20 & 0.10 \\
\hline
\end{tabular}

Table 2. Biochemical characters of Streptomyces sp. AB8

\begin{tabular}{lclc}
\hline Test & Result & Test & Result \\
\hline Glucose & + & Phenol & + \\
Fructose & + & Alkaloids & + \\
Cellulose & + & Flavonoids & - \\
Lactose & + & Saponin & - \\
Galactose & + & Triterpenoids & - \\
Sucrose & + & Anthraquinone glycosides & - \\
Chitinase & + & Tannin & - \\
Mannanase & + & Catalase & + \\
Lipase & - & Indole & + \\
Amylase & + & Protease & + \\
\hline
\end{tabular}

Note: + : positive reaction; - : negative reaction 


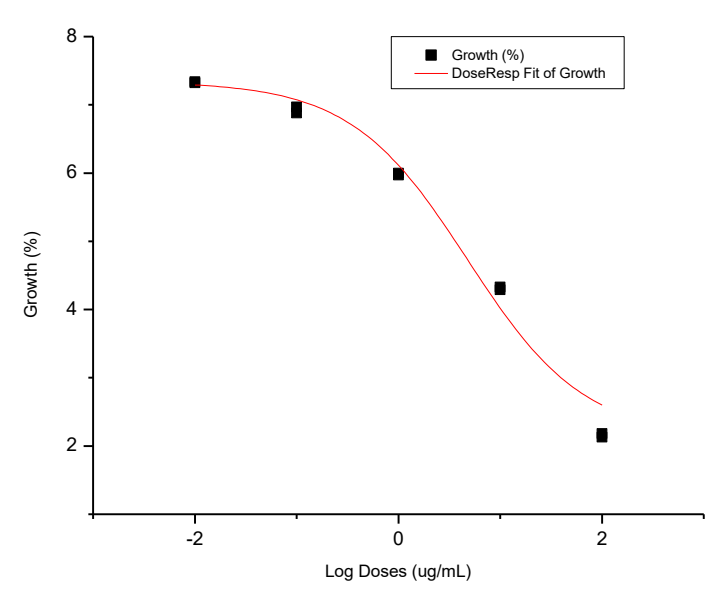

$\mathbf{A}$

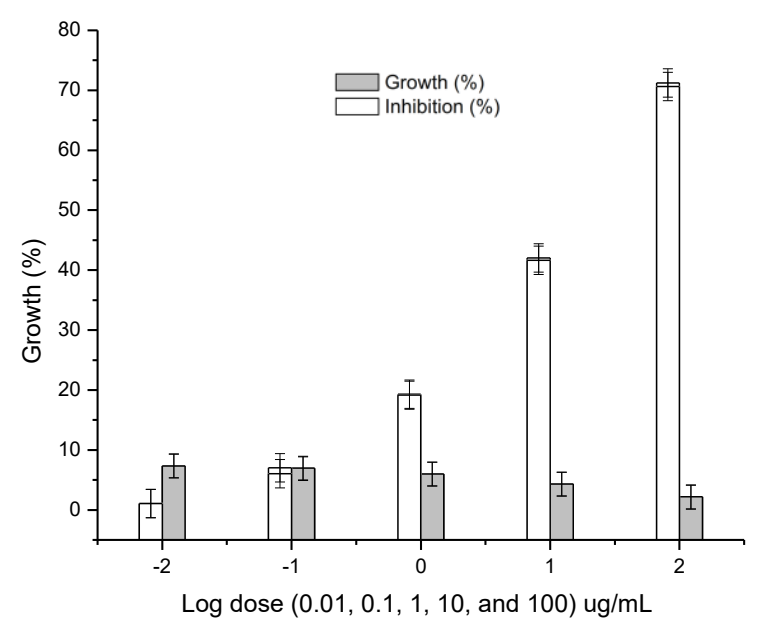

D

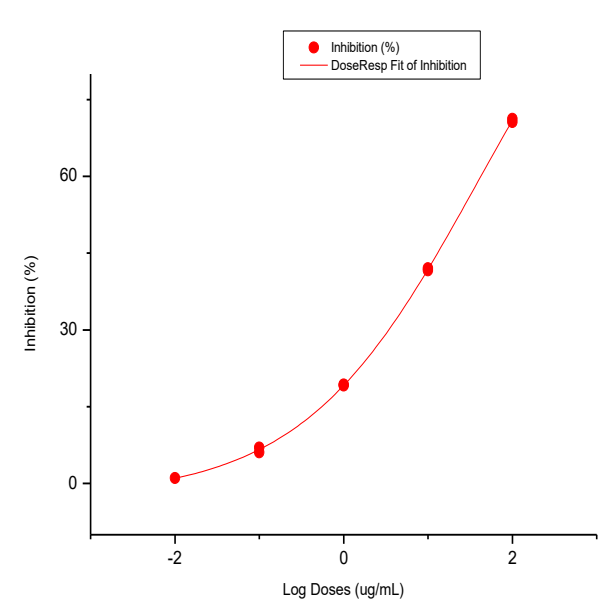

B

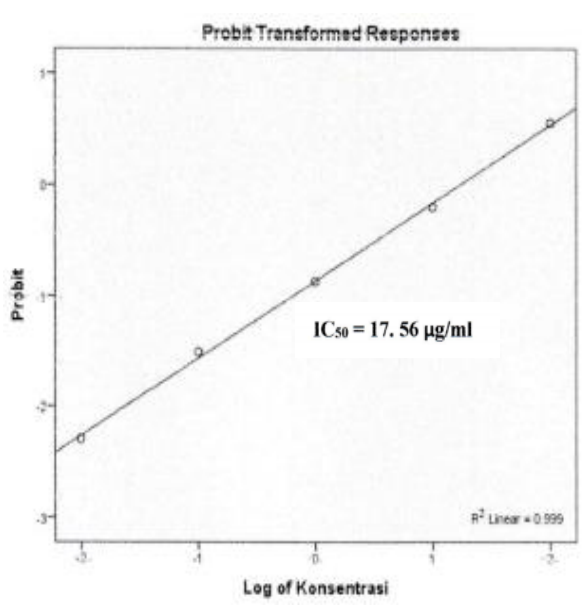

$\mathbf{E}$

Figure 2. The effect of Streptomyces extracts on growth (A), growth inhibition (B), the ratio of growth to inhibition $(\mathrm{C})$, the $\mathrm{IC}_{50}$ value of extract against Plasmodium parasites (D)

Alkaloids, which have a wide structural variation, are distinguished by the presence of a specific nitrogen atom. The majority of alkaloids have only one nitrogen atom, but others had up to five. This nitrogen was discovered in the form of a primary amine (RNH2), secondary amine $(\mathrm{R} 2 \mathrm{NH})$, or tertiary amine $(\mathrm{R} 3 \mathrm{NH})(\mathrm{R} 3 \mathrm{NH})$ (Cushnie et al. 2014). Many alkaloids contain oxygen in addition to carbon, hydrogen, and nitrogen (Cushnie et al. 2014). Figure 3 showed that there was $\mathrm{H}$ bonded $\mathrm{NH}$ at an absorbance range of $3070-3350 \mathrm{~cm}^{-1}$. This was presumed as a sign of the presence of alkaloids. The acetate and benzoic groups occurred at $1073.23 \mathrm{~cm}^{-1}$ and above, followed by double bond $-\mathrm{CH}=\mathrm{CH}$ - (cis) at $650-750 \mathrm{~cm}^{-1}$.

Phenols also present in the liquid media after the fermentation process (Table 2). It was confirmed by the emergence of spectroscopy bands around 990 until 1060 $\mathrm{cm}^{-1}$. The secondary cyclic alcohols are found at these spectra. Phenols donate hydrogen to react with reactive nitrogen and oxygen species as an antioxidant (Pereira et al. 2009). Phenols also have a variety of biochemical and pharmacological properties such as antiviral, anticancer, antimalarial, and anti-inflammatory activities.

\section{Antimalarial activity}

Streptomyces extract at a concentration of $100 \mu \mathrm{g} / \mathrm{mL}$ was able to inhibit parasite growth up to $70.92 \%$, with an average parasite growth rate of $2.15 \%$. Parasitic growth was suppressed at a rate of $4.31 \%$ with an inhibitory percentage of 41.84 percent at a concentration of 10 $\mu \mathrm{g} / \mathrm{mL}$. Extract concentration of $1 \mu \mathrm{g} / \mathrm{mL}$ resulted in parasite growth of $5.96 \%$ with an inhibition percentage of $19.23 \%$. While a concentration of $0.1 \mu \mathrm{g} / \mathrm{mL}$ resulted in inhibition of $6.55 \%$ with parasite growth of 6.93 and a concentration of $0.01 \mu \mathrm{g} / \mathrm{mL}$ resulted in inhibition of $1 \%$ with growth of $7.33 \%$. Overall, the treatment resulted in lower growth compared to the control. The increasing extract concentration was linear with inhibition, and vice versa, parasite growth increased with decreasing concentration (Figure 2). The inhibitory concentration to suppress a half parasites population $\left(\mathrm{IC}_{50}\right)$ was achieved at $17.56 \mu \mathrm{g} / \mathrm{mL}$. 


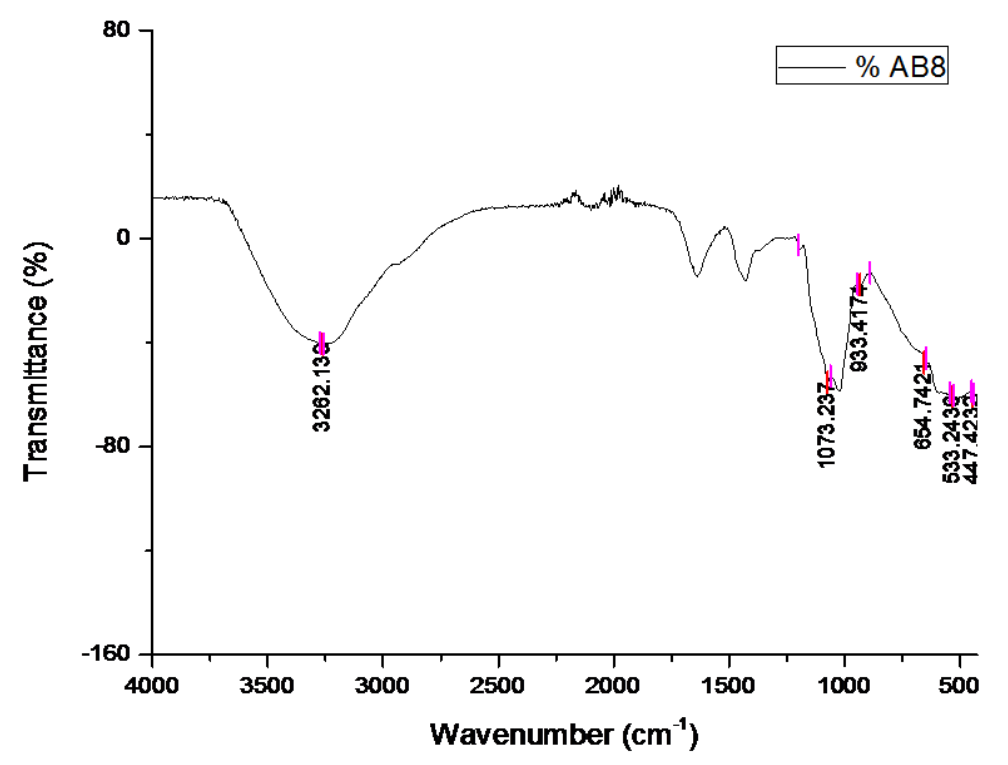

Figure 3. FT-IR spectra of crude extract produced by Streptomyces sp AB8

Several past studies have reported on the mechanism of alkaloids in preventing the growth of plasmodial and microbiological infections. Alkaloids inhibit nucleic acid synthesis by suppressing the enzyme dihydrofolate reductase in cell-free (Raimondi et al. 2019). It can prevent cell division by inhibiting the Z-ring formation in bacteria (Keffer et al. 2013). Another study by GodlewskaŻyłkiewicz et al. (2020) showed that alkaloids are sufficient to initiate bacterial homeostasis and disrupt the stability of the outer membrane and cytoplasmic (Cushnie et al. 2014). Alkaloids were also able to restrain fimbriadependent biofilm formation in E. coli (Notarte et al. 2019).

Streptomyces cellulosae strain TES17 produced phenolic compounds with strong antioxidant properties and effective in damaging lung cancer cell lines (Rani et al. 2018). The antibacterial and antimalarial mechanism of phenolic compounds possibly due to the ability to inhibit respiratory electron transport systems, reduced outer membrane containing lipopolysaccharides, disrupts the structure of the cell wall, and the synthesis of cell wall becomes inefficient, affect the permeability, and disrupt the cell division protein FtsZ-ring (Aldulaimi et al. 2019).

The findings on Streptomyces extract's antimalarial activity were used as a starting point. Further study to determine its efficacy using an ex vivo or in vitro approach is needed (Sinha et al. 2017). Peter's Test or 4-day suppression test, histopathological observation, and cytotoxicity for non-cell-targeted are required (Kifle et al. 2020). A metabolite is categorized as antiplasmodial if this metabolite can suppress parasite growth by more than $30 \%$ compared to negative controls after completing a set of in vivo tests (Castro et al. 1996). In conclusion, the qualitative test approach was supported by infrared spectroscopic data indicating the presence of phenolic compounds and alkaloids from the bacterial metabolite Streptomyces AB8. The crude extract of Streptomyces sp AB8 can inhibit Plasmodium, with an $\mathrm{IC}_{50}$ value of $17.56 \mu \mathrm{g} / \mathrm{mL}$. The extract of Streptomyces sp. AB8 could inhibit the growth of Dickeya zeae N-Unila 5, Dickeya zeae N-Unila 10, Aspergillus sp IK3, and Escherichia coli. These results on antimalarial and antimicrobial are preliminary results.

\section{ACKNOWLEDGEMENTS}

We would like to thank everyone who contributes to this research. This work was partly supported by grants from Universitas Lampung, Indonesia (1661/UN26.21/PN/ 2021). The authors have declared that there was no conflict of interests.

\section{REFERENCES}

Aeny TN, Suharjo R, Ginting C, Hapsoro D, Niswati A. 2020. Characterization and host range assessment of Dickeya zeae associated with pineapple soft rot disease in east Lampung, Indonesia. Biodiversitas 21 (2): 587-595. DOI: 10.13057/biodiv/d210221.

Agustina D, Surtiningsih T, Manuhara YS, Arifiyanto A, Malewa M. 2019. Study of Cellulase Activity Produced by Penicillium sp., Aspergillus niger and Trichoderma viride on Imperata cylindrica (L.) Beauv. Enrichment Media. IOP Conf Ser Earth Environ Sci 253 (1): 012016. DOI: 10.1088/1755-1315/253/1/012016.

Al-Ansari M, Alkubaisi N, Vijayaragavan P, Murugan K. 2019. Antimicrobial potential of Streptomyces sp. to the Gram-positive and Gram-negative pathogens. J Infect Public Health 12 (6): 861-866. DOI: $10.1016 /$ j.jiph.2019.05.016

Aldulaimi O, Drijfhout F, Uche FI, Horrocks P, Li W-W. 2019. Discovery, synthesis and antibacterial evaluation of phenolic 
compounds from Cylicodiscus gabunensis. BMC Compl Altern Med 19 (1): 183. DOI: 10.1186/s12906-019-2589-2.

Alkandahri M. Berbudi AN, Vicahyani Utami AS. 2019. Antimalarial activity of extract and fractions of Castanopsis costata (Blume) A.DC. Avicenna J Phytomed 9 (5): 474-481.

Arifiyanto A, Afriani H, Putri MH, Damayanti B, Riyanto CLR. 2021. The biological prospective of red-pigmented bacteria cultured from contaminated agar media. Biodiversitas J Biol Divers 22 (3): 11521159. DOI: $10.13057 /$ biodiv/d220310

Arifiyanto A, Surtiningsih T, Ni'matuzahroh, Fatimah, Agustina D, Alami N. 2020. Antimicrobial activity of biosurfactants produced by actinomycetes isolated from rhizosphere of Sidoarjo mud region. Biocatalysis Agric Biotechnol 24: 101513. DOI: 10.1016/j.bcab.2020.101513.

Castro O, Barrios M, Chinchilla M, Guerrero O. 1996. Chemical and biological evaluation of the effect of plant extracts against Plasmodium berghei. Revista Biol Trop 44 (2A): 361-367.

Chevrette MG, Carlson CM, Ortega HE, Thomas C, Ananiev GE, Barns KJ, Book AJ, Cagnazzo J, Carlos C, Flanigan W, Grubbs KJ. 2019. The antimicrobial potential of Streptomyces from insect microbiomes. Nat Commun 10 (1): 516. DOI: 10.1038/s41467-019-08438-0.

Cui L, Mharakurwa S, Ndiaye D, Rathod PK, Rosenthal PJ. 2015 Antimalarial drug resistance: Literature review and activities and findings of the ICEMR network. Am J Trop Med Hyg 93 (Suppl 3): 57-68. DOI: $10.4269 /$ ajtmh.15-0007

Cushnie TPT, Cushnie B, Lamb AJ.2014. Alkaloids: an overview of their antibacterial, antibiotic-enhancing and antivirulence activities. Int J Antimicrob Agents $44 \quad$ (5): $377-386 . \quad$ DOI: 10.1016/j.jiantimicag.2014.06.001

Darmawan TS, Zahroh TT, Merindasya M, Masfaridah R, Hartanti DA, Arum S, Nurhatika S, Muhibuddin A, Surtiningsih T, Arifiyanto A. 2017. Manganese (Mn) stress toward hyperaccumulators plants combination (HPC) using Jatropha curcas and lamtoro gung ( $L$. leucocephala) in mycorrhizal addition on soybean (Glycine max) seedling stage. AIP Conf Proc 1854 (1): 020027. DOI $10.1063 / 1.4985418$

de Lima Procópio RE, da Silva IR, Martins MK, de Azevedo JL, de Araújo JM. 2012. Antibiotics produced by Streptomyces. Braz J Infect Dis 16 (5): 466-471. DOI: 10.1016/j.bjid.2012.08.014

El-Naggar NEA, El-Ewasy SM. 2017. Bioproduction, characterization, anticancer and antioxidant activities of extracellular melanin pigment produced by newly isolated microbial cell factories Streptomyces glaucescens NEAE-H. Sci Rep 7: 42129. DOI: 10.1038/srep42129.

Ezeonu CS, Ejikeme CM. 2016. Qualitative and quantitative determination of phytochemical contents of indigenous Nigerian Softwoods. New J Sci 2016: 1-9. DOI: 10.1155/2016/5601327.

Fang Q, Maglangit F, Mugat M, Urwald C, Kyeremeh K, Deng H. 2020. Targeted isolation of indole alkaloids from Streptomyces sp. CT37. Molecules 25 (5): 1108. DOI: 10.3390/molecules25051108.

Fatmawaty, Rosmalena, Amalia A, Syafitri I, Prasasty VD. 2017 Antimalarial effect of flamboyant (Delonix regia) bark and papaya $($ Carica papaya $\mathrm{L}$ ) leaf ethanolic extracts against Plasmodium berghei in mice. Biomed Pharmacol J 10 (3): 1081-1089. DOI: $10.13005 / \mathrm{bpj} / 1206$

Fitri LE, Alkarimah A, Cahyono AW, Lady WN, Endharti AT, Nugraha RY. 2019. Effect of metabolite extract of Streptomyces hygroscopicus subsp. hygroscopicus on Plasmodium falciparum 3D7 in Vitro. Iran J Parasitol 14 (3): 444-452

Godlewska-Żyłkiewicz B, Świsłocka R, Kalinowska M, Golonko A, Świderski G, Arciszewska Ż, Nalewajko-Sieliwoniuk E, Naumowicz M, Lewandowski W. 2020. Biologically active compounds of plants: Structure-related antioxidant, microbiological and cytotoxic activity of selected carboxylic acids. Materials 13 (9): 4454. DOI: $10.3390 / \mathrm{ma13194454}$

Gomathi A, Gothandam KM. 2019. Investigation of anti-inflammatory and toxicity effects of mangrove-derived Streptomyces rochei strain VITGAP173. J Cell Biochem 120 (10): 17080-17097. DOI: $10.1002 /$ jcb. 28969

Hay SI, Guerra CA, Tatem AJ, Noor AM, SR. 2004. The global distribution and population at risk of malaria: past, present, and future. Lancet Infect Dis 4 (6): 327-336. DOI: 10.1016/S14733099(04)01043-6

Isaka M, Jaturapat A, Kramyu J, Tanticharoen M, Thebtaranonth Y. 2002. Potent in vitro antimalarial activity of meta cyclo prodigiosin isolated from Streptomyces spectabilis BCC 4785. Antimicrob Agents
Chemother 46 (4): 1112-1113. DOI: 10.1128/AAC.46.4.11121113.2002

Keffer JL, Huecas S, Hammill JT, Wipf P, Andreu JM, Bewley CA. 2013. Chrysophaentins are competitive inhibitors of FtsZ and inhibit Z-ring formation in live bacteria. Bioorg Med Chem 21 (18): 5673-5678. DOI: 10.1016/j.bmc.2013.07.033.

Kifle ZD, Adinew GM, Mengistie MG, Gurmu AE, Enyew EF, Goshu BT, Amare GG. 2020. Evaluation of antimalarial activity of methanolic root extract of Myrica salicifolia a rich (Myricaceae) against Plasmodium berghei-Infected mice. J Evid-Based Integr Med 25: 1-12. DOI: $10.1177 / 2515690 X 20920539$.

Li C, Ji C, Tang B. 2018. Purification, characterization and biological activity of melanin from Streptomyces sp. FEMS Microbiol Lett 365 (19): 1-8. DOI: 10.1093/femsle/fny077.

Lin YB, Wang XY, Fang H, Ma YN, Tang J, Tang M, Wei GH. 2012. Streptomyces shaanxiensis sp. nov., a blue pigment-producing streptomycete from sewage irrigation soil. Intl J Syst Evol Microbiol 62 (8): 1725-1730. DOI: 10.1099/ijs.0.029959-0.

Mathew BT, Torky Y, Amin A, Mourad AH, Ayyash MM, El-Keblawy A, Hilal-Alnaqbi A, AbuQamar SF, El-Tarabily KA. 2020. Halotolerant marine rhizosphere-competent actinobacteria promote Salicornia bigelovii growth and seed production using seawater irrigation. Front Microbiol 11. DOI: 10.3389/fmicb.2020.00552.

Mousavi B, Hedayati MT, Hedayati N, Ilkit M, Syedmousavi S. 2016. Aspergillus species in indoor environments and their possible occupational and public health hazards. Curr Med Mycol 2 (1): 36-42. DOI: 10.18869/acadpub.cmm.2.1.36.

Notarte KI, Devanadera MK, Mayor AB, Cada MC, Pecundo MH, Macabeo AP. 2019. Toxicity, antibacterial, and antioxidant activities of fungal endophytes Colletotrichum and Nigrospora spp. Isolated from Uvaria grandiflora. Philippine J Sci 148: 505-512.

Nugraha RY, Faratisha IF, Mardhiyyah K, Ariel DG, Putri FF, Winarsih S, Sardjono TW, Fitri LE. 2020. Antimalarial properties of isoquinoline derivative from Streptomyces hygroscopicus subsp. hygroscopicus: an in silico approach. BioMed Res Intl. DOI: $10.1155 / 2020 / 6135696$

Okay S, Özdal M, Kurbanoğlu EB. 2013. Characterization, antifungal activity, and cell immobilization of a chitinase from Serratia marcescens MO-1. Turk J Biol 37 (6): 639-644. DOI: 10.3906/biy1208-45.

Okokon J, Antia B, Mohanakrishnan D, Sahal D. 2017. Antimalarial and antiplasmodial activity of husk extract and fractions of Zea mays.

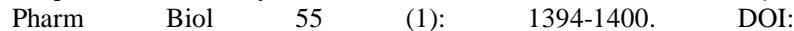
10.1080/13880209.2017.1302966.

Orabuezea CI, Ota DA, Coker HA. 2020. Antimalarial potentials of Stemonocoleus micranthus Harms (Leguminosae) stem bark in Plasmodium berghei infected mice. J Tradit Compl Med 10 (1): 7078. DOI: $10.1016 /$ j.jtcme.2019.03.001.

Pereira DM, Valentão P, Pereira JA, Andrade PB. 2009. Phenolics: From chemistry to biology. Molecules 14 (6): 2202-2211. DOI: 10.3390/molecules 14062202

Putri MH, Handayani K, Setiawan WA, Damayanti B, Ratih CL, Arifiyanto A. 2021. Screening of extracellular enzymes on Serratia marcescens strain MBC1. Jurnal Riset Biologi dan Aplikasinya 3 (1): 23-29. [Indonesian]

Quintino L, Namislo A, Davidsson M, Breger LS, Kavanagh P, Avallone M, Elgstrand-Wettergren E, Isaksson C, Lundberg C. 2019. DHFR inhibitors: Reading the past for discovering novel anticancer agents. Molecules 24 (6): 1-19. DOI: 10.3390/molecules24061140.

Rani R, Arora S, Kaur J, Manhas RK. 2018. Phenolic compounds as antioxidants and chemopreventive drugs from Streptomyces cellulosae strain TES17 isolated from rhizosphere of Camellia sinensis. BMC Compl Altern Med 18 (1): 82. DOI: 10.1186/s12906018-2154-4.

Rosa E, Ekowati CN, Handayani T, Ikhsanudin A, Apriliani F, Arifiyanto, A. 2020. Characterization of entomopathogenic fungi as a natural biological control of American cockroaches (Periplaneta americana). Biodiversitas 21 (11): 5276-5282. DOI: 10.13057/biodiv/d211131.

Sasongko A, Yopi Y, Rahmani N, Lisdiyanti P, Saepudin E. 2015. Enzymatic hydrolysis of mannan from Konjac (Amorphophallus sp.) using mannanase from Streptomyces lipmanii to produce Mannooligosaccharides. Makara J Sci 19 (3). DOI: 10.7454/mss.v19i3.4850.

Setyaningrum E, Arifiyanto A, Nukmal N, Aeny TN, Putri MH, Setiawati UN. 2021. In vitro test for inhibition of Plasmodium falciparum 3D7 parasites using Streptomyces hygroscopicus subsp. hygroscopicus 
Strain i18, Isolated from a Pineapple Farm in Lampung. J Pure Appl Microbiol 15: 891-896. DOI: 10.22207/jpam.15.2.45.

Singh BDC. 2013. Human infections and detection of Plasmodium knowlesi. Clin Microbiol Rev 26 (2): 165-84. DOI 10.1128/CMR.00079-12.

Sinha S, Sarma P, Sehgal R, Medhi B. 2017. Development in assay methods for in vitro antimalarial drug efficacy testing: A Systematic Review. Front Pharmacol 8: 754. DOI: 10.3389/fphar.2017.00754.

Sumardi, Farisi S, Ekowati CN, Arifiyanto A, Rahmawati DE. 2020 Halotolerant Bacillus sp. For mannan degradation isolated from mangrove ecosystem at Hanura beach Lampung. J Pure Appl Microbiol 14 (2): 1237-1244. DOI: 10.22207/JPAM.14.2.18.
Zeleke G, Kebebe D, Mulisa E, Gashe F. 2017. In vivo antimalarial activity of the solvent fractions of fruit rind and root of Carica papaya Linn (Caricaceae) against Plasmodium berghei in Mice. J Parasitol Res. DOI: 10.1155/2017/3121050.

Zhou H, Yang Y, Zhang J, Peng T, Zhao L, Xu L, Ding Z. 2013. Alkaloids from an endophytic Streptomyces sp. YIM66017. Nat Prod Commun 8 (10): 1393-1396. DOI: 10.1177/1934578x1300801012.

Zin NM, Baba MS, Zainal-Abidin AH, Latip J, Mazlan NW, Edrada-Ebel RA. 2017. Gancidin W, a potential low-toxicity antimalarial agent isolated from an endophytic Streptomyces SUK10. Drug Design Dev Ther 11: 351-363. DOI: 10.2147/DDDT.S121283. 